\title{
Factors influencing the vitamin D status of 10 -year-old urban South African children
}

\author{
Machuene A Poopedi*, Shane A Norris and John M Pettifor \\ MRC Mineral Metabolism Research Unit \& Birth to Twenty Research Programme, Faculty of Health Sciences, \\ Department of Paediatrics and Child Health, Chris Hani Baragwanath Hospital, The University of the \\ Witwatersrand, PO Bertsham, 2013 Johannesburg, South Africa
}

Submitted 20 September 2009: Accepted 30 June 2010: First published online 31 August 2010

\begin{abstract}
Objective: Assessment of vitamin D status in a cohort of healthy 10-year-old urban children and the factors that influence vitamin D status in these children.

Design: A cross-sectional study. Blood samples were collected across four seasons of the year for the biochemical determination of serum 25-hydroxyvitamin D [25(OH)D]. Anthropometric measurements (height and weight), BMI and total fat and lean mass (determined by the dual energy X-ray absorptiometry) were measured. 25(OH)D concentrations were assessed by chemiluminescent assay. Setting: Study of children in the Greater Johannesburg area of South Africa who form the Bone Health sub-cohort of the longitudinal Birth to Twenty cohort. Subjects: Three hundred and eighty-five children who form the Bone Health sub-cohort of the longitudinal Birth to Twenty cohort.

Results: White children had significantly higher $25(\mathrm{OH}) \mathrm{D}$ than their black peers $(120 \cdot 0(\mathrm{SD} \mathrm{36} \cdot 6) \mathrm{nmol} / 1$ v. $93 \cdot 3(\mathrm{sD} 34 \cdot 0) \mathrm{nmol} / \mathrm{l}$, respectively). Seasonal variations in $25(\mathrm{OH}) \mathrm{D}$ levels were found only in white children, with $25(\mathrm{OH}) \mathrm{D}$ levels being significantly higher in white than in black children during the autumn and summer months. In multiple regression analysis, season, ethnicity, sex and total fat mass were the factors found to have an influence on $25(\mathrm{OH}) \mathrm{D}$. Vitamin D deficiency $(7 \%)$ and insufficiency (19\%) were uncommon among the 10-year-old children.

Conclusions: Vitamin D supplementation or fortification is not warranted in healthy children living in Johannesburg. However, further studies need to confirm this in other regions of the country, especially in those living further south and with less sunshine during the winter months.
\end{abstract}

The classical role of vitamin $\mathrm{D}$ in man is to increase the absorption of calcium and phosphate from the gastrointestinal tract for the mineralisation of the skeleton. A deficiency of vitamin D leads to hypocalcaemia and bone disease (rickets or osteomalacia). Vitamin D has two main forms: vitamin $\mathrm{D}_{3}$ or cholecalciferol, which is formed in the skin after exposure to ultraviolet (UV) light; and ergocalciferol or vitamin $\mathrm{D}_{2}$, which is obtained by irradiation of ergosterol in plants and foods ${ }^{(1)}$. Serum 25-hydroxyvitamin D [25(OH)D] concentrations serve as a marker of vitamin D status; however, the optimal levels for health remain a subject of much debate ${ }^{(2)}$. This is attributed to the difficulty in reaching a consensus in defining optimal $25(\mathrm{OH}) \mathrm{D}$ concentrations not only for bone health at different ages but also for the other non-classical actions of vitamin D on cell differentiation, proliferation and function ${ }^{(3,4)}$. Some of the uncertainty has also been caused by a lack of standardisation of and variation in $25(\mathrm{OH}) \mathrm{D}$ assays ${ }^{(5)}$.

There are a variety of factors that are reported to influence vitamin D status in children and adults. These include duration of sun exposure, season, cloud cover, latitude, pollution, sunscreen use, skin coverage by clothing, ethnicity and body composition. The paucity of data on the vitamin D status of healthy children in Johannesburg has led us to assess the vitamin D status in healthy 10-year-old children and to determine the influence of body composition, seasonal change, sex and ethnicity on vitamin D status.

Our hypothesis was that children living in Johannesburg would generally be vitamin D-sufficient as Johannesburg has greater than eight sunshine hours daily throughout the year ${ }^{(G)}$; however, black children in general would have lower $25(\mathrm{OH}) \mathrm{D}$ concentrations than white children due to their higher skin pigmentation.

\section{Methods}

\section{Subjects}

This was a cross-sectional study of 475 children aged 10 years, who formed the Bone Health sub-cohort of the 
Birth to Twenty cohort. The Birth to Twenty cohort is a longitudinal study of child health and development, which has followed the development of 3273 children in the Greater Johannesburg area of South Africa since their birth in $1990^{(7)}$. The Bone Health cohort, which is a representative of the larger Birth to Twenty cohort, consists of 475 black and white children who since the age of 9 years have been intensively studied to investigate factors influencing bone mass accrual during adolescence.

The selection of the participants and cross-checks for key demographic variables between the Birth to Twenty and Bone Health cohorts have been reported elsewhere ${ }^{(8)}$. Participants with chronic illness (juvenile ideopathic arthritis, asthma or epilepsy), on medications which affect growth or bone mass development, or on mineral or vitamin D supplements were excluded. Guardians gave written informed consent for their children to be studied, and verbal assent was obtained from the children. The study protocol was approved by the Committee for Research on Human Subjects of the University of the Witwatersrand, Johannesburg (Approval no. M980810).

All children lived in Johannesburg at a latitude of approximately $26^{\circ} \mathrm{S}$ and altitude of $1750 \mathrm{~m}$. Seasons of the year for the statistical analysis of $25(\mathrm{OH}) \mathrm{D}$ concentrations were categorized as follows: autumn (March-May), winter (June-August), spring (September-November) and summer (December-February). The average daily sunshine hours and maximum temperatures in Johannesburg during the seasons are as follows: autumn $\left(8 \cdot 2 \mathrm{~h}, 22^{\circ} \mathrm{C}\right)$, winter $(9 \cdot 1 \mathrm{~h}$, $\left.18^{\circ} \mathrm{C}\right)$, spring $\left(8 \cdot 8 \mathrm{~h}, 24^{\circ} \mathrm{C}\right)$ and summer $\left(8 \cdot 2 \mathrm{~h}, 26^{\circ} \mathrm{C}\right)^{(6)}$. With regard to the sampling procedure of study participants across the seasons, eighty-two participants were sampled in autumn (seventy-two blacks and ten whites), 105 in winter (seventy-six blacks and twenty-nine whites), ninety-four in spring (ninety-one blacks and three whites) and 104 in summer (fifty-six blacks and forty-eight whites), totalling to 385 subjects.

There were major differences in socio-economic status between the black and white children. Black South African children are exposed to a multitude of factors known to impact negatively on their health in general such as poor nutrition, low dietary calcium intake, less physical activity as well as compromised growth and delayed onset of puberty compared with their white peers ${ }^{(9-14)}$.

\section{Antbropometric measurements and body composition}

Height was measured in millimetres using a wall-mounted stadiometer (Holtain, Crymych, UK) and weight in kilograms using a digital electronic instrument (Dismed, Quebec, Montreal, Canada). Both instruments were regularly calibrated and the participants wore minimal clothing when being weighed. BMI was calculated as the participant's weight in kilograms divided by the square of their height in metres $\left(\mathrm{kg} / \mathrm{m}^{2}\right)$. Total and percentage of fat mass and lean mass were measured by dual-energy X-ray absorptiometry, using a Hologic QDR 4500 instrument (Hologic Inc., Bedford, MA, USA). The data were analysed with the software supplied by the manufacturer (version $11 \cdot 2$ ).

\section{Biochemical analysis}

Blood samples $(20 \mathrm{ml})$ were drawn by venepuncture from fasting participants into plain tubes by registered nurses. The blood samples were allowed to clot for a minimum of $20 \mathrm{~min}$, the serum was aliquoted and stored in Eppendorf tubes at $-70^{\circ} \mathrm{C}$ until analysed. 25(OH)D was measured by a chemiluminescent assay using DiaSorin Liaison kits (DiaSorin, Stillwater, MN, USA). All the samples were run in duplicate. Our laboratory is currently participating in the International Vitamin D External Quality Assessment Scheme (DEQAS) and was given the certificate of efficiency, as the laboratory has achieved the performance target set by the DEQAS advisory panel, i.e. $80 \%$ or more of the results fell within $\pm 30 \%$ of the all laboratory trimmed mean. The inter-assay CV for low and higher $25(\mathrm{OH}) \mathrm{D}$ controls was $10 \%$ and $9 \%$, respectively, whereas the intra-assay CV was $8 \%$ and $6 \%$ for low and higher $25(\mathrm{OH}) \mathrm{D}$ controls, respectively. Blood samples were collected from only 385 of the 475 participants in the cohort as the others refused blood sampling, were not available, or blood samples could not be obtained.

The following categories were used to define vitamin D status: vitamin D deficiency $(<50 \mathrm{nmol} / \mathrm{l})$, insufficiency $(50-74 \mathrm{nmol} / \mathrm{l})$ and sufficiency $(\geq 75 \mathrm{nmol} / \mathrm{l})^{(2,4,15)}$.

\section{Statistical analysis}

The results are expressed as mean and SD, unless otherwise indicated. The data were analysed using the Statistica software package version 6 (StatSoft, Tulsa, OK, USA). Unpaired $t$ tests were used to compare the means of different groups. All tests were two-tailed and a $P$ value $<0 \cdot 05$ was considered statistically significant.

\section{Results}

Blood samples were available from 385 (140 black female, 47 white female, 155 black male and 43 white male participants) of the 475 children. Only those participants with $25(\mathrm{OH}) \mathrm{D}$ values were included in the study (Table 1 ).

There were no significant sex or ethnic differences with respect to age between the study groups. Black girls were heavier and taller than black boys $(P=0 \cdot 01)$. There were no significant differences in weight, height or BMI between white boys and white girls. White boys and girls were taller than their black peers $(P=0 \cdot 0001)$. There were no significant differences in BMI between any of the groups.

Girls had a higher percentage of fat and a lower percentage of lean tissue and total lean tissue than their male peers. There were no significant differences between black and white girls with respect to total fat tissue, percentage of fat or percentage of lean tissue; however, white girls had 
Table 1 Gender and ethnic differences in age, anthropometry, body composition and 25(OH)D of 10-year-old children

\begin{tabular}{|c|c|c|c|c|c|c|c|c|c|}
\hline \multirow[b]{3}{*}{ Variables } & \multicolumn{4}{|c|}{ Female } & \multicolumn{4}{|c|}{ Male } & \multirow[b]{3}{*}{$P$ value } \\
\hline & \multicolumn{2}{|c|}{ Black (n 140) } & \multicolumn{2}{|c|}{ White (n 47) } & \multicolumn{2}{|c|}{ Black (n 155) } & \multicolumn{2}{|c|}{ White ( $n$ 43) } & \\
\hline & Mean & SD & Mean & SD & Mean & SD & Mean & SD & \\
\hline Age (years) & $10 \cdot 5$ & $0 \cdot 3$ & $10 \cdot 6$ & $0 \cdot 3$ & $10 \cdot 5$ & 0.3 & $10 \cdot 6$ & 0.3 & $\begin{array}{l}P_{1}=\mathrm{NS} \\
P_{2}=\mathrm{NS}\end{array}$ \\
\hline \multicolumn{10}{|l|}{ Anthropometry } \\
\hline Weight (kg) & $34 \cdot 8^{*}$ & $8 \cdot 5$ & $35 \cdot 9$ & $7 \cdot 6$ & $32 \cdot 6^{\star}$ & $6 \cdot 4$ & $35 \cdot 8$ & $6 \cdot 8$ & \multirow{3}{*}{$\begin{array}{l}P_{1}=0.01 \text { and } 0.97 \\
P_{2}=\text { NS } \\
P_{1}=0.01 \text { and NS } \\
P_{2}=0.0001 \text { and } 0.0001 \\
P_{1}=\text { NS } \\
P_{2}=\text { NS }\end{array}$} \\
\hline Height (mm) & $139 \cdot 2^{*} \dagger$ & $6 \cdot 4$ & $143 \cdot 6+$ & $7 \cdot 3$ & $137 \cdot 3^{*}+$ & $6 \cdot 1$ & $143 \cdot 2 t$ & $7 \cdot 1$ & \\
\hline BMI $\left(\mathrm{kg} / \mathrm{m}^{2}\right)$ & $17 \cdot 8$ & $3 \cdot 4$ & $17 \cdot 2$ & $2 \cdot 3$ & $17 \cdot 2$ & $2 \cdot 6$ & $17 \cdot 4$ & $2 \cdot 5$ & \\
\hline \multicolumn{10}{|l|}{ Body composition } \\
\hline Total fat tissue (g) & $10069^{*}$ & 5166 & 9893 & 4049 & $7307^{\star}$ & 3771 & 8112 & 3462 & \multirow{4}{*}{$\begin{array}{l}P_{1}=0.0001 \text { and NS } \\
P_{2}=\mathrm{NS} \\
P_{1}=0.0001 \text { and } 0.0004 \\
P_{2}=\mathrm{NS} \\
P_{1}=0.0001 \text { and } 0.03 \\
P_{2}=0.04 \text { and } 0.0001 \\
P_{1}=0.0001 \text { and } 0.0003 \\
P_{2}=\mathrm{NS}\end{array}$} \\
\hline Fat $(\%)$ & $28^{*}$ & $7 \cdot 0$ & $27^{*}$ & $5 \cdot 5$ & $22^{*}$ & $6 \cdot 3$ & $22^{*}$ & $5 \cdot 2$ & \\
\hline Total lean tissue $(\mathrm{g})$ & $23892^{*} \dagger$ & 4009 & $25164^{*}+$ & 4020 & $24152^{*} \dagger$ & 3151 & $26825^{\star} \dagger$ & 3849 & \\
\hline Lean tissue (\%) & $70^{*}$ & $6 \cdot 8$ & $70^{*}$ & $5 \cdot 3$ & $75^{*}$ & $6 \cdot 0$ & $75^{*}$ & $5 \cdot 0$ & \\
\hline $\begin{array}{l}\text { Blood biochemistry } \\
\text { 25(OH)D (nmol//; total) }\end{array}$ & $86^{*}+$ & $31 \cdot 1$ & $112^{*} \dagger$ & $34 \cdot 8$ & $100^{*}+$ & $34 \cdot 4$ & $129^{*} \dagger$ & $37 \cdot 1$ & $\begin{array}{l}P_{1}=0.0004 \text { and } 0.02 \\
P_{2}=0.0001 \text { and } 0.0001\end{array}$ \\
\hline
\end{tabular}

25(OH)D, serum 25-hydroxyvitamin D; $P_{1}$, gender difference (black (female $v$. male) and white (female $v$. male)); $P_{2}$, ethnic difference (female (black $v$. white) and male (black $v$. white)).

A $P$ value $<0.05$ is considered statistically significant.

Mean values were significantly different between genders: ${ }^{*} P<0.05$.

Mean values were significantly different between ethnicities: $+P<0.05$.

greater total lean tissue than black girls $(P=0 \cdot 04)$. Similarly, there were no significant differences between black and white boys with respect to total fat tissue, percentage of fat or percentage of lean tissue, but white boys had greater total lean tissue than black boys $(P=0 \cdot 0001)$.

Boys (black (100 (sD 34.4) nmol/l) and white (129 (SD $37 \cdot 1) \mathrm{nmol} / \mathrm{l})$ had significantly higher $25(\mathrm{OH}) \mathrm{D}$ than girls (black (86 (sD 31·1) nmol/1) and white (112 (SD 34.8) $\mathrm{nmol} / \mathrm{l}))$ in each ethnic group $(P=0.0004$ and 0.02 for black and white children, respectively).

Seasonal variations in $25(\mathrm{OH}) \mathrm{D}$ were found in white children, with values being highest in summer and autumn. No seasonal variations were noted in black children. $25(\mathrm{OH}) \mathrm{D}$ values were significantly higher in white than black children during the autumn (whites (119 (sD 34.1) nmol/1) $v$. blacks (89 (sD 32.3) nmol/1), $P=0 \cdot 01)$ and summer months (whites (137 (SD 34.9) nmol/1) $v$. blacks (113 (SD 30.9) nmol/1), $P=0 \cdot 0001$; Fig. 1).

The percentages of black and white participants with vitamin D sufficiency were $70 \%$ and $87 \%$, respectively, whereas $22 \%$ and $12 \%$, respectively, were vitamin Dinsufficient, and $8 \%$ black and $1 \%$ white children were vitamin D-deficient. For the overall study population, 7\% had vitamin D deficiency, 19\% had vitamin D insufficiency and $74 \%$ had vitamin D sufficiency.

In both black and white children, 25(OH)D concentrations correlated negatively with the percentage of fat tissue $(r=-0 \cdot 14, P=0 \cdot 02 ;$ and $r=-0 \cdot 3, P=0 \cdot 01$,

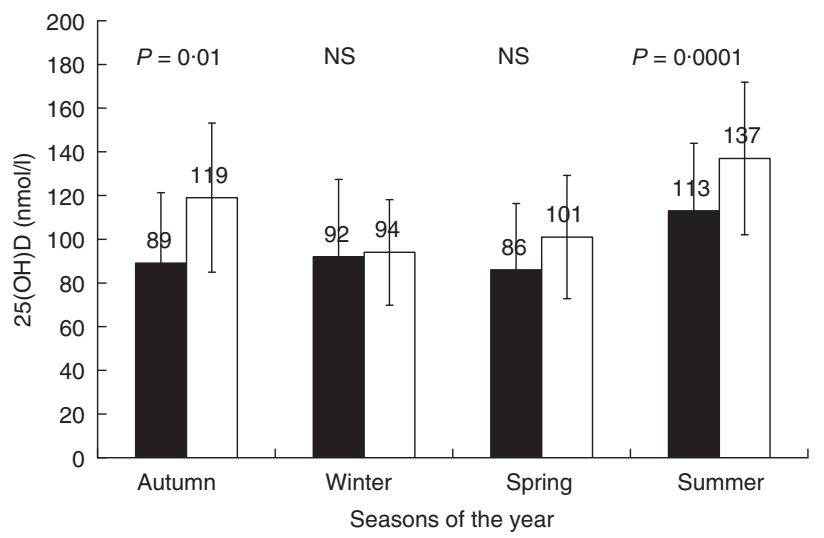

Fig. 1 Serum 25-hydroxyvitamin D [25(OH)D] concentrations $(\mathrm{nmol} / \mathrm{l})$ by season in black $(\boldsymbol{\square})$ and white $(\square)$ 10-year-old children. Values are mean and SD: black (autumn) $=89$ (SD 32.3), white (autumn) $=119$ (SD 34.1); black (winter) $=92(\mathrm{SD} 35 \cdot 3)$, black (winter) $=94(\mathrm{SD} 24 \cdot 2)$; black (spring) $=86(\mathrm{SD} 30 \cdot 4)$, white (spring) $=101$ (SD 28.2), black (summer) $=113$ (SD 30.9), white (summer) $=137(\mathrm{SD} 34 \cdot 9)$

respectively) and positively with the percentage of lean tissue $(r=0 \cdot 14, P=0 \cdot 02$ (black); and $r=0 \cdot 27, P=0 \cdot 01$ (white)). After adjusting fat mass and lean mass for height a significant correlation was found between fat mass and 25(OH)D $(r=-0 \cdot 13, P=0 \cdot 01)$.

The relationship between $25(\mathrm{OH}) \mathrm{D}$ and parathyroid hormone $(\mathrm{PTH})$ was not significant in either ethnic or gender groups (data not shown). 


\section{Discussion}

Vitamin D sufficiency was present in $74 \%$ of our study population. As we had hypothesised, vitamin D insufficiency is not a major public health issue among 10-yearold South African children living in Johannesburg. These findings differ from other studies reported from North Africa ${ }^{(16)}, \mathrm{USA}^{(17,18)}$, Europe ${ }^{(19)}$, the Middle East $^{(20,21)}$, Asia $^{(22,23)}$, New Zealand ${ }^{(24)}$ and elsewhere ${ }^{(25)}$. South Africa, and in particular Johannesburg, has abundant sunshine throughout the year ${ }^{(6)}$; thus, despite few foods being fortified with vitamin $\mathrm{D}$, vitamin D sufficiency is maintained in healthy ambulatory children. It should be noted, however, that the majority of children included in the study lived in small separate houses with yards; thus the findings might be very different if children living in high-rise apartment blocks in the inner city of Johannesburg had been studied. Factors such as latitude, the lack of excessive clothing coverage $\mathrm{e}^{(21,25-27)}$ and not living in high-rise urban inner city ghettos may have played significant roles in reducing hypovitaminosis D in the present study.

As in other studies, ethnic differences in $25(\mathrm{OH}) \mathrm{D}$ levels were found in the present study. White children had significantly higher $25(\mathrm{OH}) \mathrm{D}$ than their black peers (Table 1). The dark skin colour of black participants is known to restrict the solar UVB photons that penetrate the skin, thereby reducing the cutaneous production of vitamin $\mathrm{D}_{3}{ }^{(28)}$. Numerous studies comparing black and white young and old participants in different countries have reported that blacks have lower 25(OH)D levels than whites ${ }^{(3,18,29)}$. However, studies ${ }^{(28,30)}$ have shown that darker-skinned participants have the capacity to produce vitamin D of similar amount to light-skinned participants when exposed to prolonged UVB light. In our study, the lower 25(OH)D in black children during summer probably reflects this difference in the capacity to produce vitamin D with similar exposures.

Dietary calcium intake in this cohort of children at the age of 9 years was significantly lower in blacks of both sexes $(347 \mathrm{mg} / \mathrm{d})$, compared with white female $(719 \mathrm{mg} / \mathrm{d})$ and male participants $(778 \mathrm{mg} / \mathrm{d})^{(31)}$. Low calcium intake in black children could result in increased catabolism of $25(\mathrm{OH}) \mathrm{D}$ and thus accentuate the lower $25(\mathrm{OH}) \mathrm{D}$. We did not find a relationship between $25(\mathrm{OH}) \mathrm{D}$ and PTH in either ethnic or sex groups (data not shown), supporting the contention that the majority of children were vitamin D-replete.

One of the factors that influence vitamin D status in both young and adult participants is season. Seasonal changes in $25(\mathrm{OH}) \mathrm{D}$ levels have been reported in black and white participants and other ethnic groups ${ }^{(24,32)}$. In the present study, the effect of season on serum 25(OH)D levels was only seen in the white children. The biggest difference in $25(\mathrm{OH}) \mathrm{D}$ concentrations between black and white children was noticed during autumn and summer ( $P=0.01$ and 0.0001 , respectively), while there was no significant ethnic difference in $25(\mathrm{OH}) \mathrm{D}$ in winter and spring (Fig. 1). The reason for the lack of seasonal variation in black children is not clear, but it is interesting to speculate that black children do not spend time lying in the sun at swimming pools during the summer months because of the differences in socio-economic status and the lack of facilities in the mainly black communities. This finding of a lack of seasonal variation in black children is different to that reported in some studies of children ${ }^{(24,33)}$, but similar to others ${ }^{(29)}$. We have previously shown that in vitro vitamin $\mathrm{D}$ synthesis is relatively constant throughout the year. Thus, if skin exposure remains constant throughout the year, one would not expect major seasonal fluctuations in vitamin $\mathrm{D}$ status. In a multiple regression analysis, season $(\beta=0 \cdot 28, P=0 \cdot 0001)$, ethnicity $(\beta=-0 \cdot 29, P=0 \cdot 0001)$, sex $(\beta=-0 \cdot 16, P=0 \cdot 003)$ and total fat mass $(\beta=-0 \cdot 15$, $P=0 \cdot 01)$ were the only factors found to have an influence on $25(\mathrm{OH}) \mathrm{D}$. Higher $25(\mathrm{OH}) \mathrm{D}$ levels were found in male rather than female participants in the present study, a finding that is similar to other studies ${ }^{(24,32)}$. The gender difference in our present study may reflect the fact that male participants may spend more time outdoors (but this was not measured). Studies of physical activity in the same group of children have previously revealed that male participants have higher physical activity than their female peers in both ethnic groups $^{(34,35)}$. Some researchers have suggested that gender differences in vitamin D status may be linked to androgenrelated differences in vitamin D-binding protein levels, to differences in precursor production in the skin, to differences in 25 -hydroxylation by the liver ${ }^{(36)}$, or to gender differences in body fat. The girls in our study had significantly greater fat mass than the boys, thus possibly providing another reason for the sex differences in $25(\mathrm{OH}) \mathrm{D}$ concentrations in our cohort. Vitamin D is a fat-soluble vitamin, and the inverse relationship between $25(\mathrm{OH}) \mathrm{D}$ and fat mass has been reported previously by researchers ${ }^{(37,38)}$. This association has been attributed to the sequestration into adipocytes of vitamin D generated in the skin or orally ingested, before it can be transported to the liver and converted to $25(\mathrm{OH}) \mathrm{D}^{(37,38)}$. However, it still remains unclear whether adiposity (or a percentage of body fat) should be taken into consideration while assessing vitamin $\mathrm{D}$ requirements in the general population. We found a similar inverse relationship between fat mass and $25(\mathrm{OH}) \mathrm{D}$ in our black and white children.

In conclusion, despite seasonal variations in $25(\mathrm{OH}) \mathrm{D}$ levels, vitamin D deficiency $(25(\mathrm{OH}) \mathrm{D}<50 \mathrm{nmol} / \mathrm{l})$ and vitamin D insufficiency $(25(\mathrm{OH}) \mathrm{D}=50-74 \mathrm{nmol} / \mathrm{l})$ were uncommon findings in our black and white 10-year-old children. We therefore believe that vitamin D supplementation or fortification should not be considered in healthy South African children living in Johannesburg. Whether similar findings hold true in other regions of the country need to be confirmed; however, of particular interest would be studies in Cape Town, where an earlier study has shown only limited vitamin D synthesis in vitro from April through to September ${ }^{(39)}$. 


\section{Acknowledgements}

The present study was funded by grants from the Medical Research Council (South Africa); the University of the Witwatersrand, Johannesburg, South Africa; the Anglo American Chairman's Fund (South Africa); and the Wellcome Trust (UK). The authors have no conflict of interest to declare. M.A.P. is a PhD student. J.M.P. and S.A.N. are supervisors of the project. M.A.P. was responsible for writing of the paper and running of the blood samples for 25-hydroxyvitamin D; S.A.N. was the study supervisor for the project and its design; J.M.P. was the study cosupervisor for the project and its design. The contribution of Bone Health and Birth to Twenty staff members in data collection both past and present is greatly appreciated by the authors.

\section{References}

1. Lips P (2006) Vitamin D physiology. Prog Biophys Mol Biol 92, 4-8.

2. Holick MF (2007) Vitamin D deficiency. N Engl J Med 357, 266-281.

3. Harris SS, Soteriades E, Coolidge JA et al. (2000) Vitamin D insufficiency and hyperparathyroidism in a low income, multiracial, elderly population. J Clin Endocrinol Metab 85, 4125-4130.

4. Holick MF (2008) Vitamin D: a D-Lightful health perspective. Nutr Rev 66, S182-S194.

5. Carter GD, Carter R, Jones J et al. (2004) How accurate are assays for 25-hydroxyvitamin D? Data from the international vitamin D external quality assessment scheme. Clin Chem 50, 2195-2197.

6. South African Climate Information (2009) Average of Daily Sunshine Hours, 1961-1970. South African Weather Bureau. http://weatherwiki.wikispaces.com/climates + of + the+world (accessed June 2009).

7. Richter LM, Norris SA \& de Wet T (2004) Transition from Birth to Ten to Birth to Twenty: the South African cohort reaches 13 years of age. Paediatr Perinat Epidemiol 18, 290-301.

8. Vidulich L, Norris SA, Cameron N et al. (2006) Differences in bone size and bone mass between black and white 10-yearold South African children. Osteoporos Int 17, 433-440.

9. Mackeown JM, Pedro TM \& Norris SA (2007) Energy, macro- and micronutrient intake among a true longitudinal group of South African adolescents at two interceptions (2000 and 2003): the Birth-to-Twenty (Bt20) Study. Public Health Nutr 10, 635-643.

10. McVeigh JA, Norris SA \& de Wet T (2004) The relationship between socio-economic status and physical activity patterns in South African children. Acta Paediatr 93, 982-988.

11. McVeigh JA, Norris SA \& Pettifor JM (2007) Bone mass accretion rates in pre- and early-pubertal South African black and white children in relation to habitual physical activity and dietary calcium intakes. Acta Paediatr 96, 874-880.

12. Pettifor JM, Ross P, Moodley G et al. (1979) Calcium deficiency in rural black children in South Africa - a comparison between rural and urban communities. $A m J$ Clin Nutr 32, 2477-2483.

13. Willey BA, Cameron N, Norris SA et al. (2009) Socioeconomic predictors of stunting in preschool children $-\mathrm{a}$ population-based study from Johannesburg and Soweto. S Afr Med J 99, 450-456.

14. Cameron N \& Wright CA (1990) The start of breast development and age at menarche in South African black females. S Afr Med J 78, 536-539.

15. Holick MF (2009) Vitamin D status: measurement, interpretation, and clinical application. Ann Epidemiol 19, 73-78.

16. Allali F, El AS, Khazani $\mathrm{H}$ et al. (2009) High prevalence of hypovitaminosis D in Morocco: relationship to lifestyle, physical performance, bone markers, and bone mineral density. Semin Arthritis Rheum 38, 444-451.

17. Harris SS \& Dawson-Hughes B (1998) Seasonal changes in plasma 25-hydroxyvitamin D concentrations of young American black and white women. Am J Clin Nutr 67, $1232-1236$.

18. Harris SS (2006) Vitamin D and African Americans. J Nutr 136, 1126-1129.

19. Outila TA, Karkkainen MU \& Lamberg-Allardt CJ (2001) Vitamin D status affects serum parathyroid hormone concentrations during winter in female adolescents: associations with forearm bone mineral density. Am J Clin Nutr 74, 206-210.

20. El-Hajj Fuleihan G, Nabulsi M, Choucair M et al. (2001) Hypovitaminosis D in healthy schoolchildren. Pediatrics 107, E53.

21. Gannage-Yared $\mathrm{MH}$, Chemali $\mathrm{R}$, Yaacoub $\mathrm{N}$ et al. (2000) Hypovitaminosis D in a sunny country: relation to lifestyle and bone markers. J Bone Miner Res 15, 1856-1862.

22. Agarwal KS, Mughal MZ, Upadhyay P et al. (2002) The impact of atmospheric pollution on vitamin D status of infants and toddlers in Delhi, India. Arch Dis Child 87, $111-113$.

23. Harinarayan CV, Ramalakshmi T, Prasad UV et al. (2008) Vitamin D status in Andhra Pradesh: a population based study. Indian J Med Res 127, 211-218.

24. Rockell JE, Green TJ, Skeaff CM et al. (2005) Season and ethnicity are determinants of serum 25-hydroxyvitamin D concentrations in New Zealand children aged 5-14 years. J Nutr 135, 2602-2608.

25. el-Sonbaty MR \& Abdul-Ghaffar NU (1996) Vitamin D deficiency in veiled Kuwaiti women. Eur J Clin Nutr 50, 315-318.

26. Ghannam NN, Hammami MM, Bakheet SM et al. (1999) Bone mineral density of the spine and femur in healthy Saudi females: relation to vitamin D status, pregnancy, and lactation. Calcif Tissue Int 65, 23-28.

27. Mishal AA (2001) Effects of different dress styles on vitamin $\mathrm{D}$ levels in healthy young Jordanian women. Osteoporos Int 12, 931-935.

28. Clemens TL, Adams JS, Henderson SL et al. (1982) Increased skin pigment reduces the capacity of skin to synthesise vitamin D3. Lancet 1, 74-76.

29. Stein EM, Laing EM, Hall DB et al. (2006) Serum 25hydroxyvitamin D concentrations in girls aged $4-8$ year living in the southeastern United States. Am J Clin Nutr $\mathbf{8 3}$, 75-81.

30. Lo CW, Paris PW \& Holick MF (1986) Indian and Pakistani immigrants have the same capacity as Caucasians to produce vitamin $\mathrm{D}$ in response to ultraviolet irradiation. Am J Clin Nutr 44, 683-685.

31. McVeigh JA, Norris SA, Cameron N et al. (2004) Associations between physical activity and bone mass in black and white South African children at age 9 year. J Appl Physiol 97, 1006-1012.

32. Dawson-Hughes B, Harris SS \& Dallal GE (1997) Plasma calcidiol, season, and serum parathyroid hormone concentrations in healthy elderly men and women. Am J Clin Nutr 65, 67-71. 
33. Looker AC, Dawson-Hughes B, Calvo MS et al. (2002) Serum 25-hydroxyvitamin D status of adolescents and adults in two seasonal subpopulations from NHANES III. Bone 30, 771-777.

34. McVeigh JA, Norris SA \& de Wet T (2004) The relationship between socio-economic status and physical activity patterns in South African children. Acta Paediatr $\mathbf{9 3}$ 982-988.

35. McVeigh JA, Norris SA \& Pettifor JM (2007) Bone mass accretion rates in pre- and early-pubertal South African black and white children in relation to habitual physical activity and dietary calcium intakes. Acta Paediatr 96, 874-880.
36. Carnevale V, Modoni S, Pileri M et al. (2001) Longitudinal evaluation of vitamin D status in healthy subjects from southern Italy: seasonal and gender differences. Osteoporos Int 12, 1026-1030.

37. Arunabh S, Pollack S, Yeh J et al. (2003) Body fat content and 25-hydroxyvitamin D levels in healthy women. J Clin Endocrinol Metab 88, 157-161.

38. Wortsman J, Matsuoka LY, Chen TC et al. (2000) Decreased bioavailability of vitamin D in obesity. Am J Clin Nutr $\mathbf{7 2}$, 690-693.

39. Pettifor JM, Moodley GP, Hough FS et al. (1996) The effect of season and latitude on in vitro vitamin $\mathrm{D}$ formation by sunlight in South Africa. S Afr Med J 86, 1270-1272. 